\title{
Antioxidant and Antiradical Properties of Some Examples of Flavonoids and Coumarins-Potentiometric Studies
}

\author{
Elena Gerasimova (D), Elena Gazizullina (D), Ekaterina Radosteva and Alla Ivanova *(D) \\ Chemical Technological Institute, Ural Federal University Named after the First President of Russia B. N. Yeltsin, \\ 620002 Ekaterinburg, Russia; e.l.gerasimova@urfu.ru (E.G.); e.r.gazizullina@urfu.ru (E.G.); \\ radostevacat@yandex.ru (E.R.) \\ * Correspondence: a.v.ivanova@urfu.ru
}

check for updates

Citation: Gerasimova, E.; Gazizullina, E.; Radosteva, E.; Ivanova, A. Antioxidant and Antiradical Properties of Some Examples of Flavonoids and Coumarins-Potentiometric Studies. Chemosensors 2021, 9, 112. https:// doi.org/10.3390/chemosensors9050112

Academic Editor: Maria Luz Rodriguez-Mendez

Received: 31 March 2021

Accepted: 12 May 2021

Published: 18 May 2021

Publisher's Note: MDPI stays neutral with regard to jurisdictional claims in published maps and institutional affiliations.

Copyright: (c) 2021 by the authors. Licensee MDPI, Basel, Switzerland. This article is an open access article distributed under the terms and conditions of the Creative Commons Attribution (CC BY) license (https:/ / creativecommons.org/licenses/by/ $4.0 /)$.

\begin{abstract}
A comprehensive study of a range of flavonoids and coumarins is presented in this article. The work uses an approach that evaluates the activity of these compounds by various mechanisms: the electron transfer (ET), the hydrogen atom transfer (HAT), and the mechanism of metal chelation. The studies were carried out using the methods of the cyclic voltammetry and the potentiometry. The electrochemical behavior of these compounds was studied by the method of cyclic voltammetry; the main types of voltammograms, depending on the oxidation mechanisms, were identified. Various versions of potentiometric sensor systems have been used to detect analytical signal in approaches implemented in ET, HAT and metal chelation mechanisms. The antioxidant capacity was studied by the electron-transfer mechanism. Compounds with antioxidant properties were selected; half-reaction periods for these compounds have been determined. It has been shown that electron-donating and complexing properties directly depend on the mutual arrangement of hydroxyl groups in the molecule. The antiradical ability of the compounds has been studied. It was shown that all studied compounds inhibit peroxyl radicals. Series on the change in antioxidant and antiradical properties of compounds have been compiled. There is no correlation between the results of the study of antioxidant properties obtained using sensory systems that reveal various antioxidant mechanisms. The need to use an integrated approach in the study of antioxidant properties is shown.
\end{abstract}

Keywords: flavonoids; coumarins; sensory systems; antioxidant capacity; antiradical capacity; cyclic voltammetry; potentiometry

\section{Introduction}

In recent decades, the search for natural sources of biologically active substances has become highly acute despite the large number of synthetic drugs used in modern medicine [1,2]. It is known that the use of herbal drugs is explained not only by their high biological activity, but also by the absence of adverse reactions inherent in synthetic drugs [3,4]. One of the most important types of biological activity is antioxidant activity $[5,6]$.

Numerous studies indicate that exogenous antioxidants play an important role as a health-protecting factor [5-7]. The main sources of natural antioxidants are medicinal and food plants. Derivatives of flavonoids and coumarins are a rather promising class of plant physiologically active compounds [8-11]. Its conjugated $\pi$-electron system of these compounds allows the ready donation of electron or hydrogen atoms [12]. This class of compounds also has other types of biological activity in addition to antioxidant properties. The sources of some derivatives of flavonoids and coumarins and their type of biological activity are shown in Table 1. 
Table 1. Sources and directions of the biological activity of some derivatives of flavonoids and coumarins.

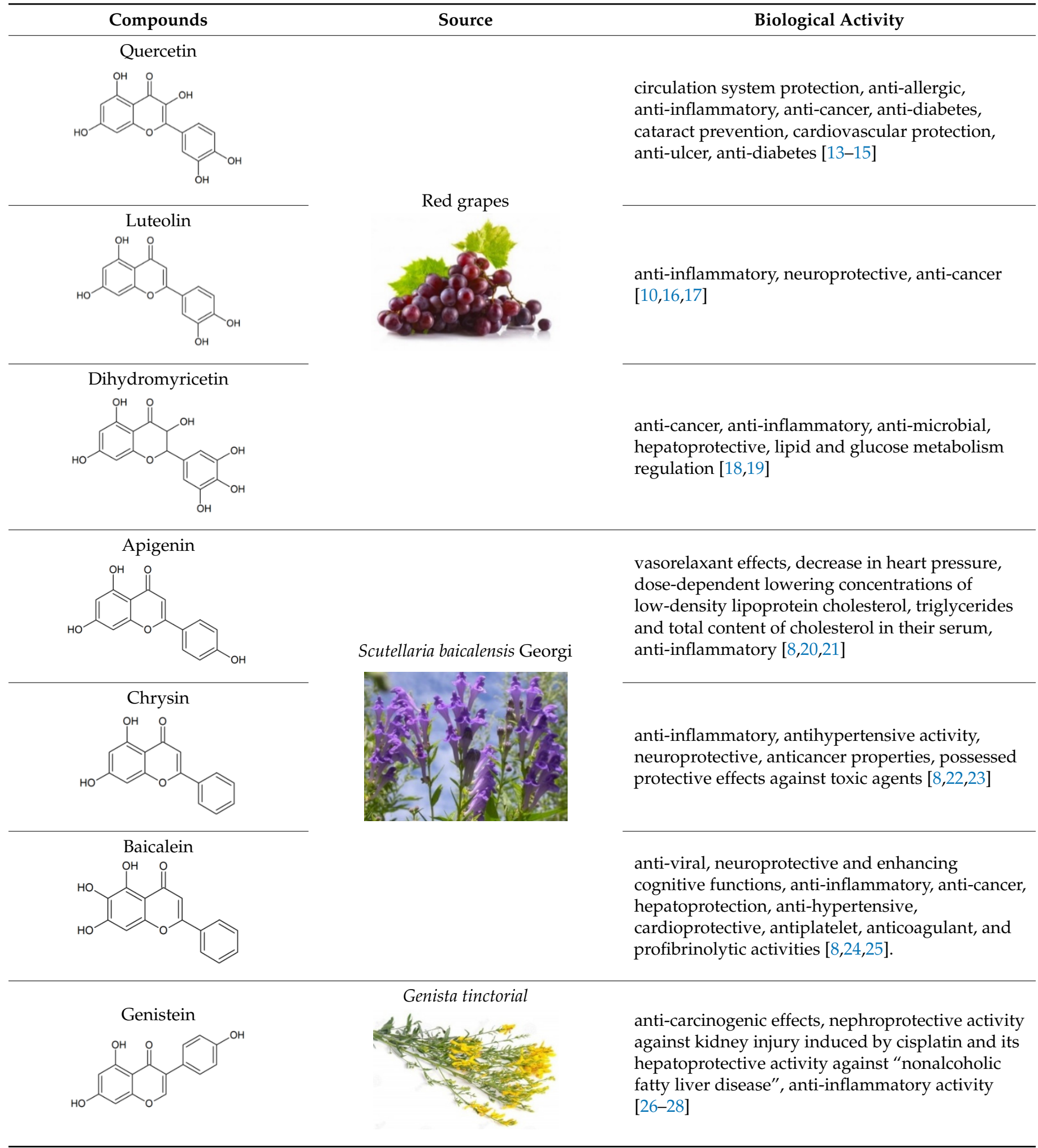


Table 1. Cont.

Biological Activity
Silybum marianum

4-Methylesculetin<smiles>Cc1cc(=O)oc2cc(O)c(O)cc12</smiles>

anti-inflammatory, neuroprotective properties [34]

4-Methyldaphnetin<smiles>Cc1cc(=O)oc2c(O)c(O)ccc12</smiles>

inhibit selectively the proinflammatory 5-lipoxygenase enzyme [35]

Synthetic

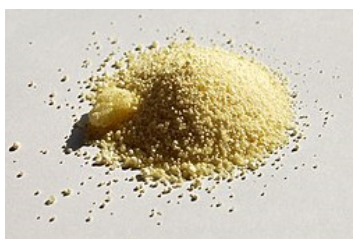

high potency against cyclooxygenase [35]

in the process of research

Currently, many publications related to the study of the antioxidant properties of individual representatives of polyphenols are presented in the literature [8-13]. However, no articles were found that included the study of a number of natural coumarins and flavonoids using integrated approaches such as those presented in this work. The biological effect of antioxidants in the human body is very diverse: the inhibition of radical formation by activated oxygen metabolites, the local decrease of oxygen concentration, change in structural organization, the chelation of metal ions of variable valency, and the convert 
peroxides to stable products [36-42]. AOs in the human body can be classified into three types of reactions in terms of their chemical transformation. Accordingly, the mechanisms of antioxidant action can be divided into three types: the electron transfer (ET-mechanism), the proton transfer (HAT-mechanism), and the mechanism of complexation (Chelatingmechanism) [39-43]. It should be noted that all three mechanisms are realized with the participation of electrons: only electron transfer (ET); hydrogen atom transfer, which in aqueous media can be considered as electron transfer accompanied by proton transfer (HAT); chelation, which is the transfer of an electron pair from a ligand to a metal. From this point of view, electrochemical methods are quite promising for studying antioxidant properties by various mechanisms. In this case, processes with the participation of electrons, as a rule, are accompanied by a change in the electrochemical parameters of the system-in particular, the potential of the system. Antioxidant properties following one or another mechanism can be studied depending on the proposed version of the electrochemical sensor system.

Earlier [44-46], we developed approaches and potentiometric sensor systems based on non-radical and radical oxidants, which make it possible to implement ET, HAT, and the chelating metals mechanism. High degrees of correlation with independent conventional methods, the Folin assay, the DPPH assay (inhibition of the stable radical of 2,2-diphenyl-1picrylhydrazyl), the TAS (total antioxidant status) Randox, and others [44-48] have been shown. The measurement results were calculated by the shift or regular change in the system potential and expressed as the integral parameter of the antioxidant capacity or the antiradical capacity, respectively. In the strict sense, the potential is solution components activity function in the field of electrochemical research, in particular, in the potentiometry. The term "activity" means "the effective (apparent) concentration of the components, taking into account the various interactions between them in solution". In the sensor systems that we have proposed, the potential is directly related to the thermodynamic activity of the solution components used as oxidizing agents and reacting with antioxidants via the mechanisms of the electron transfer and the electron-proton transfer. However, in this case, the parameter should be called "capacity".

By the term "capacity", we mean the integral parameter indirectly related to the thermodynamic activity of antioxidants through the potential of the sensory system. The "capacity" reflects the total content of antioxidants capable of interacting with the reagent in the reactions of electron transfer-the antioxidant capacity (AOC) and in the reactions of the hydrogen atom transfer-the antiradical capacity (ARC). This approach is consistent with the antioxidant research recommendation that "antioxidant capacity measures the thermodynamic conversion efficiency of an oxidant probe upon reaction with an antioxidant" [49].

The aim of this work is the comprehensive study of individual substances flavonoids and coumarins of natural and synthetic origin using approaches that allow assessing the activity of these compounds by various mechanisms: the ET-mechanism, the HATmechanism and the chelating metals mechanism.

\section{Materials and Methods}

\subsection{Reagents and Objects of Analysis}

All reagents were of analytical grade: $\mathrm{K}_{3}\left[\mathrm{Fe}(\mathrm{CN})_{6}\right], \mathrm{K}_{4}\left[\mathrm{Fe}(\mathrm{CN})_{6}\right], \mathrm{KH}_{2} \mathrm{PO}_{4}, \mathrm{Na}_{2} \mathrm{HPO}_{4} \cdot 12 \mathrm{H}_{2} \mathrm{O}$, (Reachim ${ }^{\circledR}$, Moscow, Russia); 2,2-azobis(2-methylpropionamidine)dihydrochloride, quercetin, luteolin, dihydromyricetin, apigenin, chrysin, baicalein, genistein, silybin, nordalbergin, 4-methylesculetin, 4-methyldaphnetin, 4-methyl-5,7-dihydroxycoumarin, 7,8-dihydroxy4-methyl-chroman- 3-toluene-2-one (Sigma-Aldrich ${ }^{\circledR}$, St. Louis, MI, USA). Solutions of antioxidants were prepared in ethanol (Rosbio ${ }^{\circledR}$, St. Petersburg, Russia).

\subsection{Cyclic Voltammetry}

Voltammetric measurements were carried out using $\mu$ AUTOLAB Type III potentiostat/galvanostat (Metrohm Autolab, Holland). A glassy carbon electrode (Metrohm, 
Holland) was used as a working electrode, a silver chloride electrode (Metrohm, Holland) as a reference electrode, and a glassy carbon rod (Metrohm, Holland) as an auxiliary electrode. Cyclic voltammograms were obtained in a phosphate buffer solution-ethanol 1:1 with a scan rate of $0.05 \mathrm{~V} / \mathrm{s}$. The scanning rate was selected based on the conditions for obtaining pronounced and reproducible peaks of oxidation of the studied compounds. The antioxidant concentration $\mathrm{C}_{\mathrm{AO}}$ was $0.1 \mathrm{mM}$. Cyclic voltammetry experiments were replicated three times.

\subsection{Sensor System for Determining Antioxidant Capacity (AOC)}

Potentiometric measurements were carried out using the $\mathrm{pH}$-meter "Expert-pH" (Econics-Expert, Moscow, Russia) with the function of measuring EMF and RS-232 interface. The measurements were taken by means of EPV-1 redox-platinum electrode and EVL-1 $\mathrm{mol} / \mathrm{dm}^{3}$ silver-silver chloride electrode $\left(\mathrm{Ag} / \mathrm{AgCl} / 3 \mathrm{~mol} / \mathrm{dm}^{3} \mathrm{KCl}\right)($ Gomelsky ZIP, Gomel, Belarus).

The determination of total antioxidant capacity (AOC) was carried out by the potentiometric method using the interaction reaction of antioxidants with the oxidizing agent $\mathrm{K}_{3}\left[\mathrm{Fe}(\mathrm{CN})_{6}\right]$. The antioxidant capacity is the effective concentration of $\mathrm{K}_{3}\left[\mathrm{Fe}(\mathrm{CN})_{6}\right]$ reacted with an antioxidant. The AOC expressed in universal units (mol-eq/L) and was calculated by Formulas (1) and (2) [44-48]. The number of equivalents in the AO molecule as a rule corresponds to the number of functional antioxidant groups involved in the electron-transfer process.

$$
\begin{gathered}
\mathrm{AOC}=\frac{C_{O x}-\alpha c_{R e d}}{1+\alpha} \cdot q \\
\alpha=\left(C_{O x} / C_{R e d}\right) 10^{\left(E_{2}-E_{1}\right) F / 2.3 R T}
\end{gathered}
$$

where $c_{O x}$ is the $\mathrm{K}_{3}\left[\mathrm{Fe}(\mathrm{CN})_{6}\right]$ concentration, $\mathrm{mol} / \mathrm{L} ; c_{R e d}$ is the $\mathrm{K}_{4}\left[\mathrm{Fe}(\mathrm{CN})_{6}\right]$ concentration, $\mathrm{mol} / \mathrm{L} ; E_{1}$ is a potential measured before the introduction of a test sample, $\mathrm{V} ; E_{2}$ is the potential measured after the addition of the test sample, $\mathrm{V}$; $R$ is the universal gas constant, $R=8.31 \mathrm{~J} / \mathrm{K} \cdot \mathrm{mol} ; T$ is the temperature, $K$.

Studies were performed at $\mathrm{pH}=7.4$ in PBS. The concentrations of $\mathrm{K}_{3}\left[\mathrm{Fe}(\mathrm{CN})_{6}\right]$ / $\mathrm{K}_{4}\left[\mathrm{Fe}(\mathrm{CN})_{6}\right]$ in an electrochemical cell were $0.01 \mathrm{~mol} / \mathrm{L} / 0.0001 \mathrm{~mol} / \mathrm{L}$, respectively. The antioxidant concentration in the electrochemical cell $\mathrm{C}_{\mathrm{AO}}$ was $0.1 \mathrm{mM}$.

The reaction half-life $\left(t_{1 / 2}, s\right)$ of studied compounds with the oxidizing agent was determined by the potentiometric method from the kinetic curve of the AOC change on time, as the time during which $50 \%$ of the obtained antioxidant capacity was recorded $\left(\mathrm{AOC}_{1 / 2}=\mathrm{AOE} / 2 \mathrm{~mol} / \mathrm{L}\right)[44]$.

\subsection{Sensor System for Determining Antiradical Capacity (ARC)}

The basis for the definition of total antiradical capacity (ARC) is a regular change in the redox potential of the reaction of antioxidants with peroxyl radicals generated during the thermal decomposition of 2,2'-azobis (2-amidinopropane) dihydrochloride [46,47].

The determination of the antiradical capacity (ARC) was carried out to the Formula (3):

$$
\mathrm{ARC}=W_{i} \cdot \tau
$$

where ARC is the antiradical capacity, mol-eq $/ \mathrm{L} ; W_{i}$ is the the generation rate of peroxyl radicals, $\mathrm{mol} / \mathrm{L} \cdot \mathrm{s}\left(W_{i}=2 \times 10^{-7} \mathrm{M} / \mathrm{s}\right) ; \tau$ is the induction period, $\mathrm{s}$.

The number of equivalents in the $\mathrm{AO}$ molecule usually corresponds to the number of functional antioxidant groups involved in the inhibition of one radical chain.

The induction period is determined as the time from the introduction of the antioxidant into the initiator solution to the point corresponding to the maximum rate of change of the potential $(\mathrm{dE} / \mathrm{dt})_{\max }$, which is defined as the maximum of the derivative function in the dependence of the redox potential on time.

Studies were performed at $\mathrm{pH}=7.4$ in $\mathrm{PBS}$ and $37^{\circ} \mathrm{C}$. 
The LOIP LT-205a circulating thermostat (LOIP, St. Petersburg, Russia) was used for temperature control cells $\left(37^{\circ} \mathrm{C}\right)$. The initiator concentration in the electrochemical cell is $0.1 \mathrm{M}$; the antioxidant concentration in the cell is $0.1 \mathrm{mM}$.

\section{Results}

A number of natural derivatives of flavonoids and coumarins were studied in the work: quercetin, luteolin, dihydromyricetin, apigenin, chrysin, baicalein, genistein, silybin; as well as derivatives of coumarin of natural (nordalbergin) and synthetic origin (4-methylesculetin, 4-methyldaphnetin, 4-methyl-5,7-dihydroxycoumarin, 7,8-dihydroxy-4-methyl-chroman3-toluene-2-one.

\subsection{The Investigation of Electrochemical Activity by Cyclic Voltammetry}

According to results of cyclic voltammetry, it can be noted that the type of voltammogram directly depends on the relative position of hydroxyl groups in the molecule. The obtained voltammograms can be conditionally divided into three groups by type:

- The presence of an oxidation peak in the potential range of 0.21 to $0.28 \mathrm{~V}$ (Figure 1). Such compounds include luteolin, nordalbergin, 4-methylesculetin, 4-methyldaphnetin, and 7,8-dihydroxy-4-methyl-chroman-3-toluene-2-one. Compounds of this group contain in their structure a catechol fragment, which is characterized by reversible oxidation-reduction and an uncomplicated process of electron transfer from the antioxidant molecule [46,50-52].

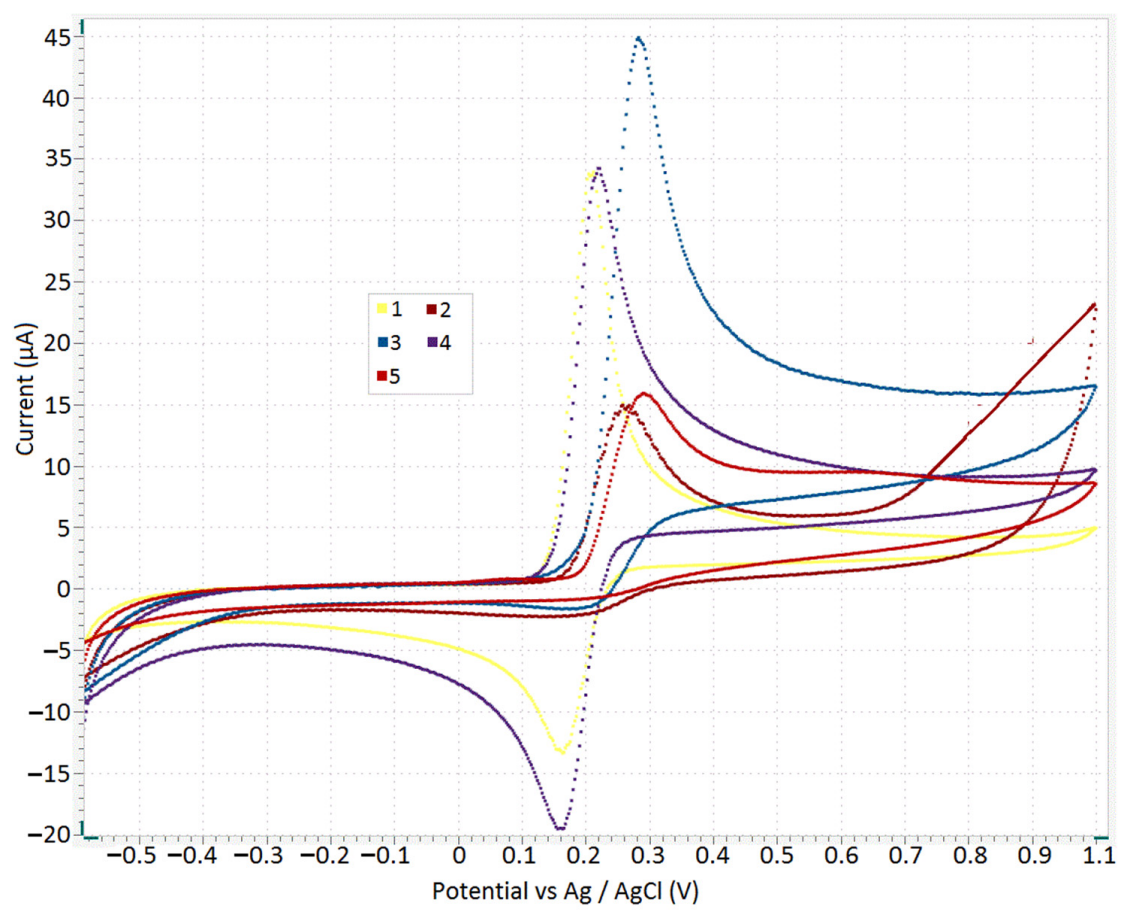

Figure 1. Cyclic voltammograms of 7,8-dihydroxy-4-methyl-chroman-3-toluene-2-one (1), Luteolin (2), 4-Methylesculetin (3), 4-Methyldaphnetin (4), and Nordalberginluteolin (5) recorded on a glassy carbon electrode, reference electrode-silver chloride electrode, $\mathrm{C}(\mathrm{AO})=0.1 \mathrm{mM}$. Background: phosphate buffer solution-ethanol 1:1. Scan rate is $0.05 \mathrm{~V} / \mathrm{s}$.

- The presence of two peaks of oxidation: the position of the first peak is in the potential range of 0.08 to $0.11 \mathrm{~V}$ and the position of the second peak is in a more positive range of potentials. These compounds include quercetin, dihidromyricetin, and baicalein (Figure 2). The compounds contain a catechol/pyrogall fragment. The presence of two peaks may indicate a stepwise oxidation process [50-53]. In this case, oxidation in the second stage can be difficult. 


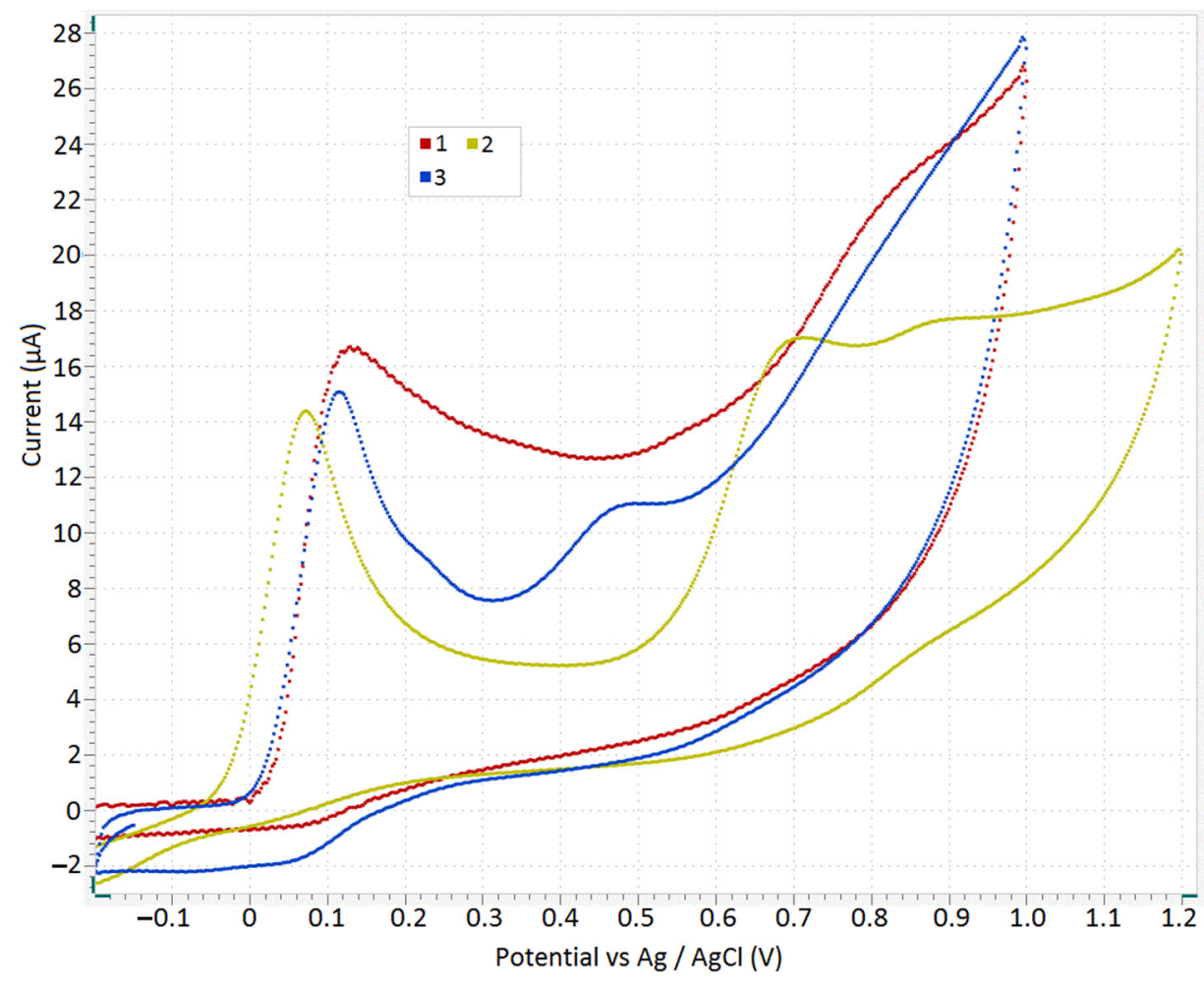

Figure 2. Cyclic voltammograms of Dihidromyricetin (1), Baicalein (2), and Quercetin (3) recorded on a glassy carbon electrode, reference electrode-silver chloride electrode, $\mathrm{C}_{\mathrm{AO}}=0.1 \mathrm{mM}$. Background: phosphate buffer solution-ethanol 1:1. Scan rate is $0.05 \mathrm{~V} / \mathrm{s}$.

The stepwise oxidation of quercetin has been established in other studies (Scheme 1) [54].<smiles>O=C1C=CC(C2Oc3cc(O)cc(O)c3C(=O)C2=O)=CC1=O</smiles>

Scheme 1. Quercetin oxidation reaction.

- The last group is characterized by the presence of an oxidation peak in a rather positive potential range ( 0.50 to $0.80 \mathrm{~V}$ ) (Figure 3$)$. These compounds include silybin, chrysin, genistein, apigenin, and 4-methyl-5,7-dihydroxycoumarin. The compounds of this group contain a resorcinol fragment, which is characterized by hindered electron 
transfer from functional $\mathrm{OH}$ groups of molecules and, as a rule, lack of antioxidant action by the electron transfer mechanism [46,50-53].

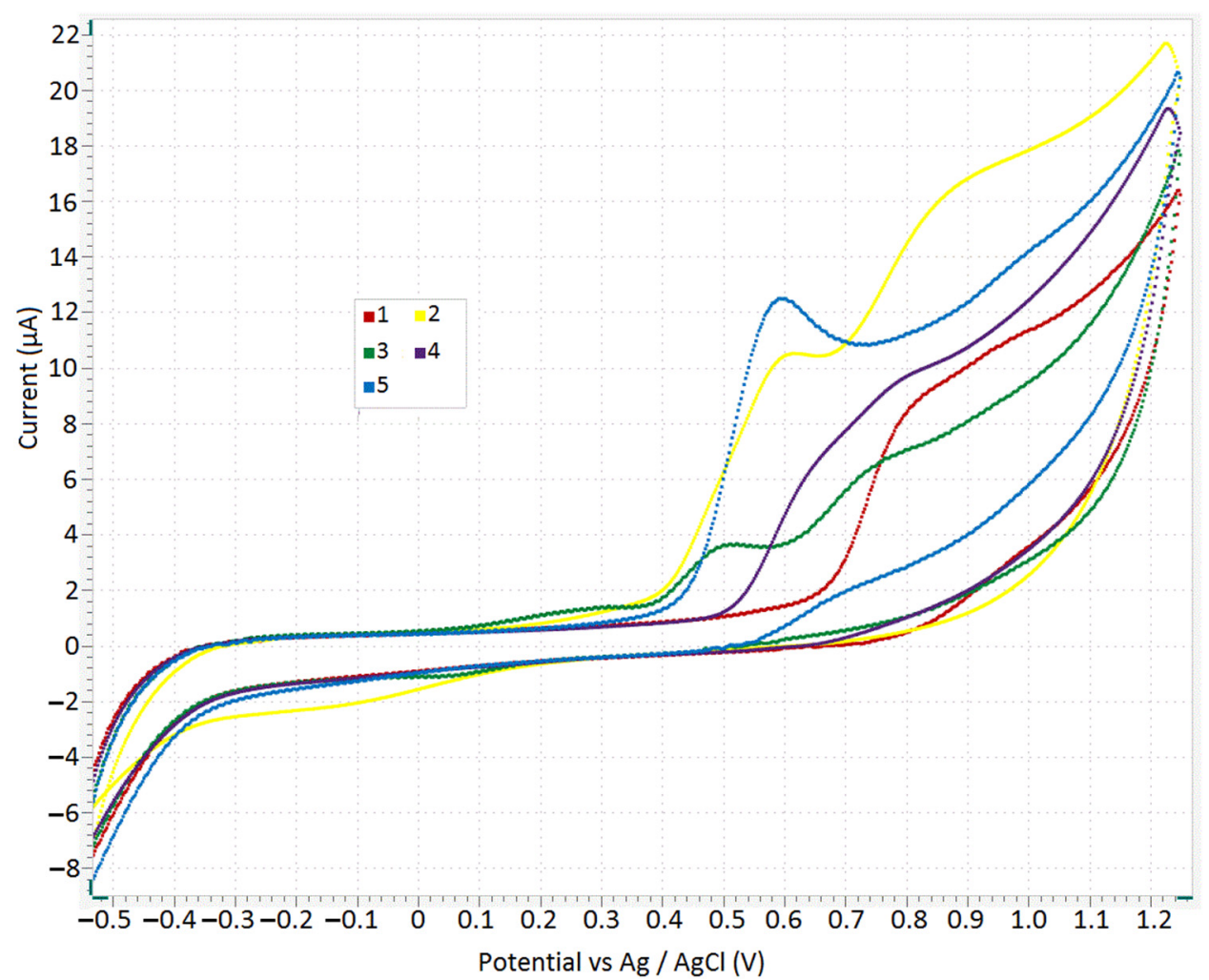

Figure 3. Cyclic voltammograms of Chrysin (1), Genistein (2), Silybin (3), Apigenin (4), 4-methyl-5,7dihydroxycoumarin (5) recorded on a glassy carbon electrode, reference electrode-silver chloride electrode, $\mathrm{C}_{\mathrm{AO}}=0.1 \mathrm{mM}$. Background: phosphate buffer solution-ethanol 1:1. Scan rate is $0.05 \mathrm{~V} / \mathrm{s}$.

The obtained patterns are consistent with both the literature data [50-56] and with the patterns obtained by us in the study of other polyphenolic compounds [46]. Table 2.

The values of the potentials of the antioxidant oxidation peaks are presented in

Table 2. Potentials of antioxidant oxidation peaks.

\begin{tabular}{|c|c|c|c|}
\hline Group Number & Name & $E_{o x}, V$ & $E_{\text {reox }}, V$ \\
\hline \multirow{5}{*}{1} & Luteolin & 0.25 & 0.21 \\
\hline & Nordalbergin & 0.28 & 0.18 \\
\hline & 4-Methylesculetin & 0.28 & 0.21 \\
\hline & 4-methyldaphnetin & 0.22 & 0.16 \\
\hline & $\begin{array}{l}\text { 7,8-dihydroxy-4-methyl-chroman- } \\
\text { 3-toluene-2-one }\end{array}$ & 0.21 & 0.16 \\
\hline \multirow{3}{*}{2} & Quercetin & 0.110 .46 & - \\
\hline & Dihydromyricetin & 0.110 .80 & - \\
\hline & Baicalein & 0.070 .68 & - \\
\hline \multirow{5}{*}{3} & Silybin & 0.500 .77 & - \\
\hline & Chrysin & 0.80 & - \\
\hline & Genistein & 0.580 .56 & - \\
\hline & Apigenin & 0.66 & - \\
\hline & 4-methyl-5,7-dihydroxycoumarin & 0.59 & - \\
\hline
\end{tabular}




\subsection{The Research of the Total Antioxidant Capacity by Potentiometric Sensor System}

The potentiometric method using the $\mathrm{K}_{3}\left[\mathrm{Fe}(\mathrm{CN})_{6}\right] / \mathrm{K}_{4}\left[\mathrm{Fe}(\mathrm{CN})_{6}\right]$ system applies electron transfer-based assays (4):

$$
\mathrm{n}\left[\mathrm{Fe}(\mathrm{CN})_{6}\right]^{3-}+\mathrm{In}=\mathrm{n}\left[\mathrm{Fe}(\mathrm{CN})_{6}\right]^{4-}+\mathrm{In}_{\mathrm{Ox}}
$$

where $\mathrm{In}$-inhibitor, $\mathrm{In}_{\mathrm{Ox}}$ - oxidized inhibitor.

In this case, the choice of $\mathrm{K}_{3}\left[\mathrm{Fe}(\mathrm{CN})_{6}\right]$ as an oxidizing agent is justified theoretically and experimentally, as the optimal model for studying antioxidant properties of compounds by the electron-transfer mechanism [44-48]. This method is aimed at measuring the recovery ability of compounds and is a very important parameter, because it reflects redox characteristics of studied compounds and the thermodynamic possibility of interaction with ROS. Methods for assessing antioxidant properties using potassium hexacyanoferrate (III) as an oxidizing agent model are quite widespread and tested on objects of various nature.

It should be noted that kinetic characteristics are important in the study of biologically active substances, since they allow the identification of compounds of fast and long action $[57,58]$.

Each group of compounds has its own advantages. On the one hand, compounds, that undergo fairly rapid transformations in the human body can produce a rapid therapeutic effect. On the other hand, compounds that react slowly can cause a long-acting action and maintain the constant level of this substance in the human body. Thus, the increased and decreased concentration of the substance is eliminated.

The potentiometric method presented in this work allows us to evaluate not only the thermodynamic parameters of the interaction reaction of antioxidants with the oxidizing agent, such as the antioxidant capacity, but also kinetic parameters, for example, the halfreaction periods of the studied antioxidants with the iron (III). The values of the antioxidant capacity and half-reaction periods of the studied antioxidants with the iron (III) are shown in Table 3.

Table 3. AOC and half-reaction periods of studied antioxidants $\left(\mathrm{C}_{\mathrm{AO}}=10^{-4} \mathrm{M}, n=5, p=0.95\right)$.

\begin{tabular}{|c|c|c|c|c|}
\hline No. & Name & AOC, $10^{-4}$ M-eq & RSD, \% & $\tau_{1 / 2}, \mathrm{c}$ \\
\hline 1 & Quercetin & $5.26 \pm 0.26$ & 4.66 & 10 \\
\hline 2 & 4-Methylesculetin & $3.56 \pm 0.12$ & 3.53 & 4 \\
\hline 3 & Chrysin & \multicolumn{3}{|c|}{ not found } \\
\hline 4 & Genistein & \multicolumn{3}{|c|}{ not found } \\
\hline 5 & Silybin & \multicolumn{3}{|c|}{ not found } \\
\hline 6 & Luteolin & $3.90 \pm 0.12$ & 3.43 & 4 \\
\hline 7 & Apigenin & \multicolumn{3}{|c|}{ not found } \\
\hline 8 & 4-methyldaphnetin & $5.00 \pm 0.09$ & 1.75 & 363 \\
\hline 9 & $\begin{array}{l}\text { 7,8-dihydroxy-4-methyl-chroman- } \\
\text { 3-toluene-2-one }\end{array}$ & $4.10 \pm 0.08$ & 2.44 & 4 \\
\hline 10 & 4-methyl-5,7-dihydroxycoumarin & \multicolumn{3}{|c|}{ not found } \\
\hline 11 & Nordalbergin & $3.69 \pm 0.06$ & 1.56 & 1 \\
\hline 12 & Baicalein & $2.46 \pm 0.02$ & 0.65 & 1 \\
\hline 13 & Dihydromyricetin & $5.67 \pm 0.06$ & 1.09 & 6 \\
\hline
\end{tabular}

It can be seen from Table 2 that rather low values of the half-reaction periods are characteristic for all tested compounds that showed activity, with the exception of 4methyldaphnetin. Accordingly, these compounds have a high reaction rate of interaction with the iron (III). This is quite expected, since many natural compounds are characterized by the rapidity of transformation. In this case, rather high values of the reaction rate of interaction with the iron (III) were recorded for a number of synthesized compounds. This is quite important information for the classification of these compounds in terms of the action speed and the possibility of long-acting action [58]. 
Thus, data on the presence of antioxidant properties of studied compounds by the electron-transfer mechanism are completely correlated with data of the cyclic voltammetry. Compounds containing hydroxyl groups in the ortho-position in their molecules are direct donors of electrons in the electron-transfer reactions, while the electron donation is difficult if hydroxyl groups are in the meta position. Such compounds, as a rule, do not exhibit pronounced antioxidant properties by the electron-transfer mechanism.

The correlations between the value of the oxidation peak potential (the first peak for compounds with stepwise oxidation) and the AOC value are shown in Figure 4 . The electron-transfer process is facilitated for most compounds. Accordingly, the peak of antioxidant oxidation is located in the more negative region $\left(\mathrm{E}_{\mathrm{ox}}\right)$; the compound $\mathrm{AOC}$ $\left(\mathrm{r}=0.84, n=7, \mathrm{r}_{\text {Crit }}=0.63\right)$ is higher. The baicalein is an exception.

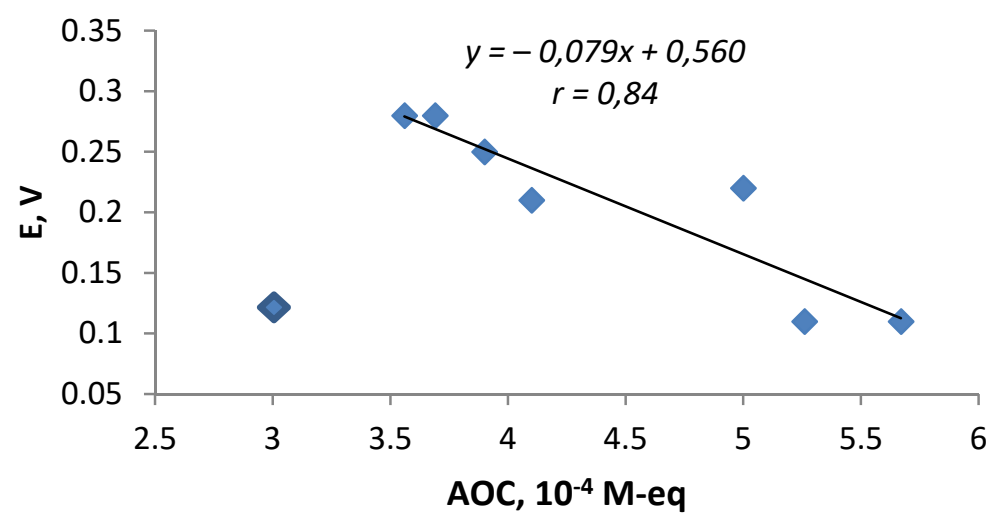

Figure 4. Correlation between the oxidation peak potential and the AOC.

In the literature, oxidation schemes are usually described with the participation of two or three electrons for similar structures. However, quite high values of stoichiometric coefficients in the reaction with potassium hexacyanoferrate (III) were obtained by studying the antioxidant properties of the compounds. Such values are associated not only with the electron-transfer mechanism, but also with the mechanism of possible complexation with iron ions $[12,42,59]$. It is known that peroxides decompose with the formation of a highly reactive hydroxyl radical in the presence of metals of variable valence $[60,61]$. This process plays a key role in DNA damage. Polyphenolic compounds containing catechol or gall structures are able to form stable complexes with metals of variable valency and inhibit radical processes at the stage of chain branching (Scheme 2):

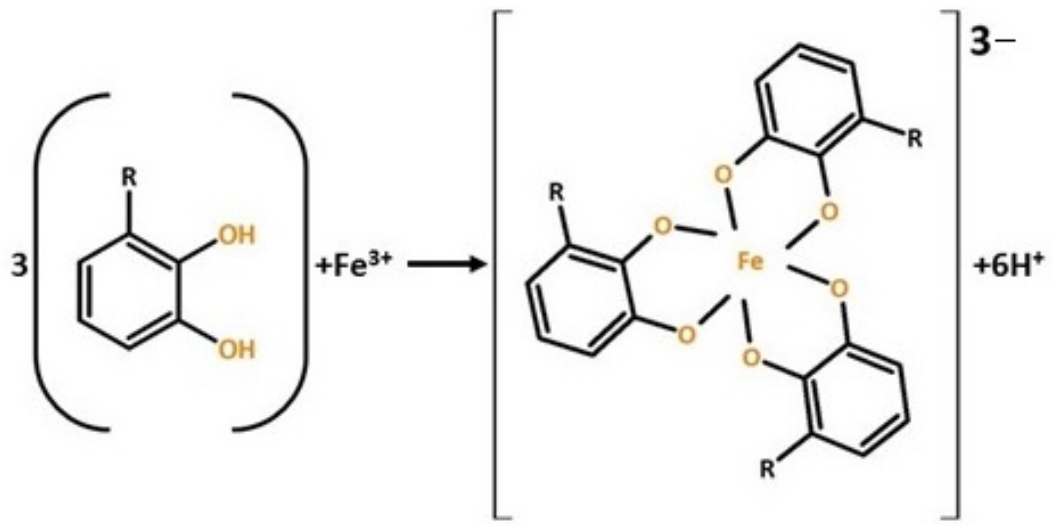

Scheme 2. Reaction of complexation of polyphenolic compounds with $\mathrm{Fe}^{3+}$ [62].

According to the scheme, iron ions are able to coordinate up to three molecules of compounds (in this case, flavonoids and coumarins) containing hydroxyl groups in the ortho-position. It is known that these complexes are quite stable. The values of the total 
stability constants for some natural flavonoids are from 27 to 46 . In particular, the stability constant $(\beta)$ of iron (III) complexes with quercetin $(\mathrm{Qu})$ from the compounds studied in this work is reliably known [42].

$$
\beta=\frac{\left[\mathrm{Fe}(\mathrm{Qu})_{3}\right]^{3-}}{\left[\mathrm{Fe}^{3+}\right] \cdot\left[\mathrm{Qu}^{2-}\right]^{3}}=10^{44}
$$

These values are significantly higher than the values of iron complexes with known complexing agents, such as EDTA, o-phenanthroline, 2,2'-dipyridyl, salicylic acid, etc. [63]. As for the stability of iron cyanide complexes, they are commensurate with the stability of iron complexes with some flavonoids [44]. It should be noted that the ability to form donor-acceptor bonds with metals is directly related to the electron-donor properties of an antioxidant; therefore, it is logical that antioxidants with hydroxyl groups in the ortho-position in a molecule are characterized by both electron-transfer reactions and complexation reactions with iron. Therefore, the antioxidant capacity determined in this experiment is an integral value, which is the result of both the iron reduction in the potassium hexacyanoferrate (III) and its chelation.

\subsection{The Research of the Total Antiradical Capacity (ARC) by Potentiometric Sensor System}

The antiradical capacity of the studied compounds with respect to peroxyl radicals was determined by hydrogen atom transfer-based assays using potentiometry according to the reaction:

$$
\mathrm{ArOH}+\mathrm{RO}_{2}^{\bullet} \rightarrow \mathrm{ArO}^{\bullet}+\mathrm{ROOH}
$$

It should be noted that antioxidants play a key role in the regulation of oxidation in chemical and biochemical systems, as inhibitors of free radical oxidation reactions [5-7]. From this point of view, the use of radical-generating systems as an oxidizer, as a model reaction of continuous generation of radicals in the human body, is the closest to real physiological conditions $[47,64,65]$. Therefore, this method is quite close to real radical processes and allows one to evaluate antiradical properties of compounds from the standpoint of the hydrogen atom transfer-based mechanism.

The AOC and ARC values of the studied compounds are shown in Figure 5.

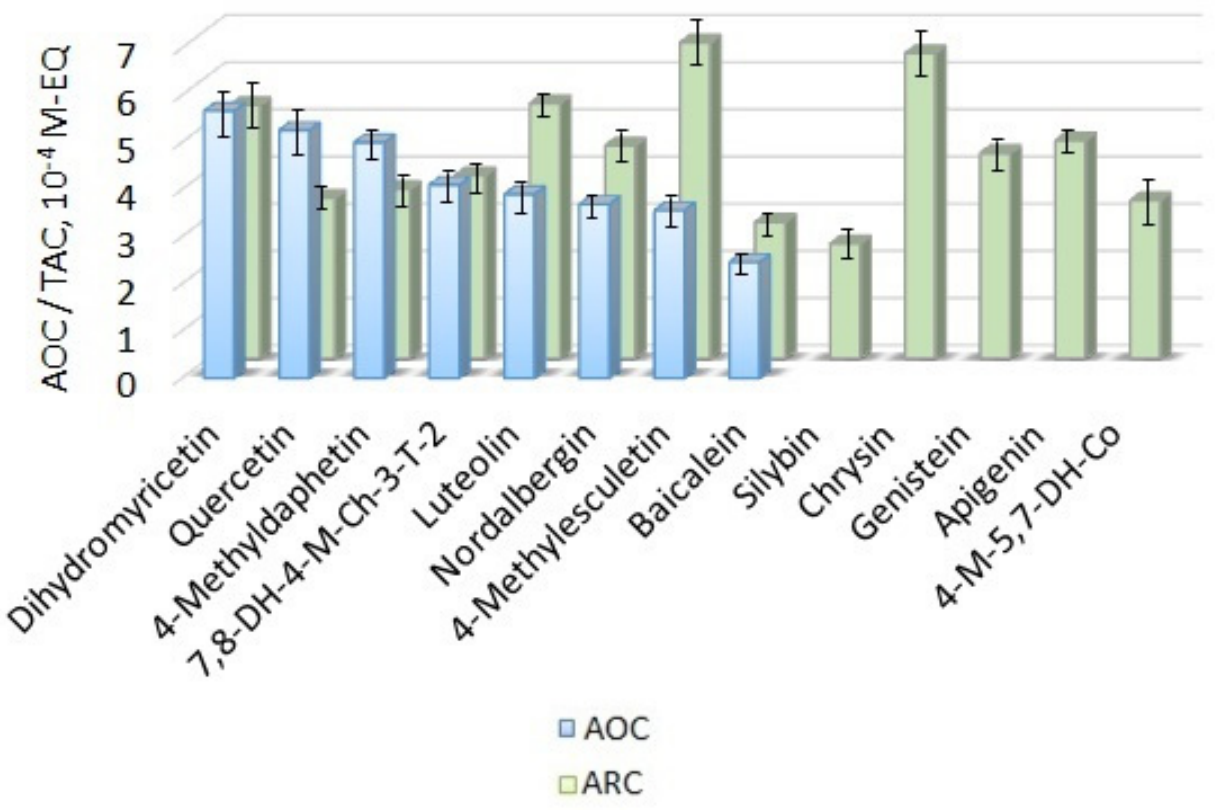

Figure 5. AOC and ARC of flavonoids and coumarins. 
As can be noted that results of determining the antioxidant capacity (AOC) and antiradical capacity (ARC) do not correlate with each other. The value change dynamics of AOC and ARC in the order of increase are shown in Table 4. Data on the change of antioxidant properties in the series of some flavonoids obtained experimentally by us are consistent with data obtained by other researchers by calculation [50].

Table 4. AOC and ARC of flavonoids and coumarins $\left(\mathrm{C}_{\mathrm{AO}}=10^{-4} \mathrm{M}, n=5, p=0.95\right)$.

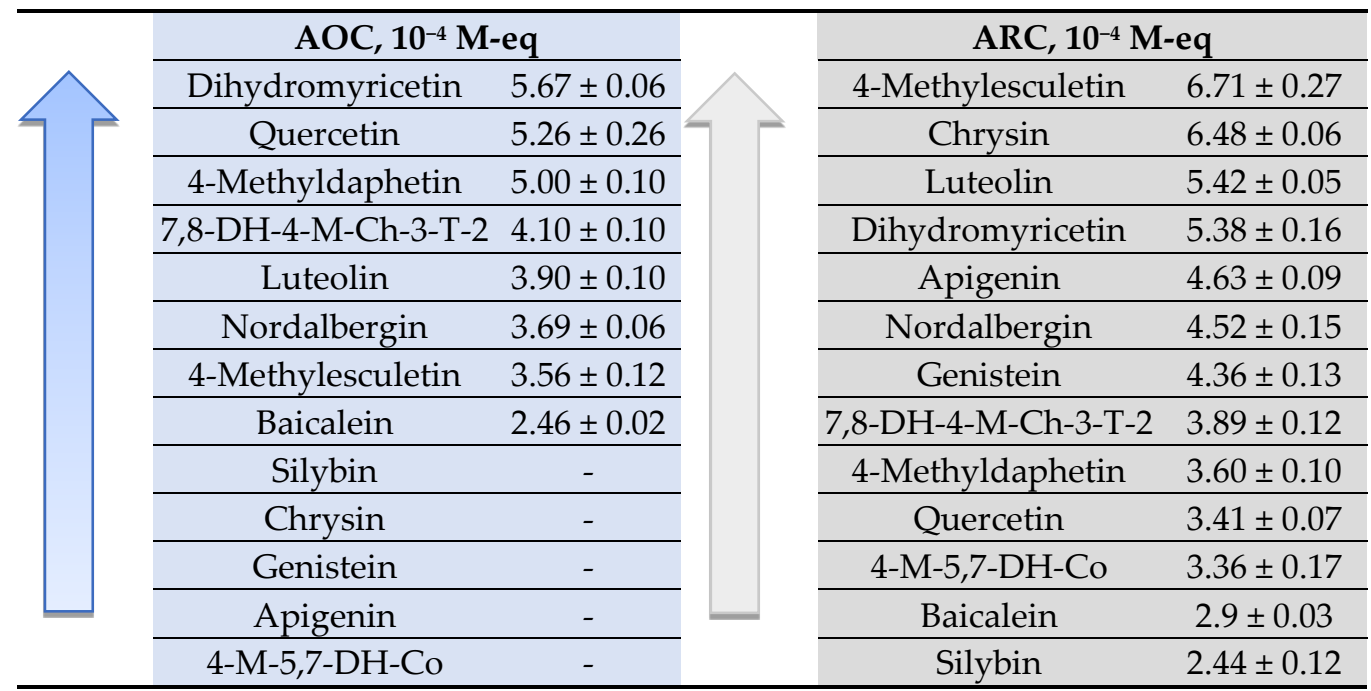

As can be noted, the results of determining the antioxidant capacity (AOC) and antiradical capacity (ARC) do not correlate with each other. This is due to the difference in the mechanisms that are implemented in these methods. The AOC value provides information on the antioxidant activity mediated by the ET-mechanism and the chelation mechanism. The ARC parameter is responsible for the antioxidant activity via the HAT-mechanism. Since antioxidants in the human body are able to realize their biological action by each of the mechanisms, the use of a method based on one of the mechanisms will provide limited information about the antioxidant properties of the compound. The existence of various mechanisms of $\mathrm{AO}$ action and the data that the ability to scavenge radicals is directly related to the donor ability of a compound to hydrogen atoms and does not correlate only with redox potentials [66] suggest that it is necessary to use integrated approaches to obtain complete information about antioxidant properties of the studied compounds [67]. For example, silybin, chrysin, genistein, apigenin, 4-methyl-5,7-dihydroxycoumarin substances, which did not show AOC, have a rather high ability to inhibit radical reactions, while from the point of view of inhibition of radical reactions, all studied compounds are promising.

\section{Conclusions}

This work was the first to conduct the comprehensive study of a number of derivatives of flavonoids and coumarins, which may be potential sources of exogenous natural antioxidants, using potentiometric sensor systems implementing electron-transfer, hydrogen atom transfer and chelating metals mechanisms. The antioxidant capacity of the electron-transfer mechanism is possessed by: Dihydromyricetin $>$ Quercetin $>4$ Methyldaphetin $>$ 7,8-dihydroxy-4-methyl-chroman-3-toluene-2-one $>$ Luteolin $>$ Nordalbergin $>4$-Methylesculetin $>$ Baicalein. The correlation between oxidation potential and AOC has been established. These compounds are promising from the point of view of their chelating ability. All the studied compounds showed their ability to inhibit generation reactions of peroxyl radicals and ARC decreased in the series: 4-Methylesculetin $>$ Chrysin $>$ Luteolin $>$ Dihydromyricetin $>$ Apigenin $>$ Nordalbergin $>$ Genistein $>7,8-$ Dihydroxy-4-methyl-chroman-3-toluene-2-one $>$ 4-Methyldaphetin $>$ Quercetin $>4$-Methyl5,7-dihydroxycoumarin $>$ Baicalein. Thus, the studied natural flavonoids and coumarins 
are promising exogenous antioxidants, and their sources are quite promising raw materials for extraction and consumption. In addition, it was shown that the synthetic derivatives of the coumarins, studied in this work, are potential antioxidants, regardless of the main therapeutic effect.

The prospect of using potentiometry for the study of compounds with antioxidant properties, realized by various mechanisms of antioxidant action, is shown. However, taking into account the mechanisms variety of the biological action of antioxidants in the body and the fact that the ability to transfer an electron, hydrogen atom and electron pairs from an antioxidant to a model oxidizer or AOM does not always correlate with each other, the integrated approach is required to obtain objective information about antioxidant properties of the studied object, which will be based on the use of several methods that implement and combine various mechanisms of the chemical transformation of antioxidants.

Author Contributions: Conceptualization, A.I., E.G. (Elena Gerasimova); methodology, A.I., E.G. (Elena Gerasimova) and E.G. (Elena Gazizullina); investigation, E.G. (Elena Gazizullina) and E.R.; data curation, E.G. (Elena Gazizullina) and E.R.; writing-original draft preparation, E.G. (Elena Gazizullina) and E.R.; writing-review and editing, A.I., E.G. (Elena Gerasimova). All authors have read and agreed to the published version of the manuscript.

Funding: The work was carried out with financial support from the Ministry of Science and Higher Education of the Russian Federation, State Contract no. FEUZ-2020-0058 (H687.42B.223/20).

Institutional Review Board Statement: Not applicable.

Informed Consent Statement: Not applicable.

Conflicts of Interest: The authors declare no conflict of interest.

\section{References}

1. Cheng, C.; Li, Z.Z.; Zhao, X.; Liao, C.L.; Quan, J.; Bode, A.M.; Cao, Y.; Luo, X.J. Natural alkaloid and polyphenol compounds targeting lipid metabolism: Treatment implications in metabolic diseases. Eur. J. Pharmacol. 2020, 870, 172922. [CrossRef] [PubMed]

2. Dhir, A. Natural polyphenols in preclinical models of epilepsy. Phytother. Res. 2020, 34, 1268-1281. [CrossRef] [PubMed]

3. Silva, R.F.M.; Pogacnik, L. Polyphenols from Food and Natural Products: Neuroprotection and Safety. Antioxidants $2020,9,61$. [CrossRef] [PubMed]

4. Bian, Y.; Wei, J.T.; Zhao, C.S.; Li, G.R. Natural Polyphenols Targeting Senescence: A Novel Prevention and Therapy Strategy for Cancer. Int. J. Mol. Sci. 2020, 21, 684. [CrossRef] [PubMed]

5. Neha, K.; Haider, M.R.; Pathak, A.; Yar, M.S. Medicinal prospects of antioxidants: A review. Eur. J. Med. Chem. 2019, 178, 687-704. [CrossRef]

6. Ali, S.S.; Ahsan, H.; Zia, M.K.; Siddiqui, T.; Khan, F.H. Understanding oxidants and antioxidants: Classical team with new players. J. Food Biochem. 2020, 44, e13145. [CrossRef]

7. Pisoschi, A.M.; Pop, A. The role of antioxidants in the chemistry of oxidative stress: A review. Eur. J. Med. Chem. 2015, 97, 55-74. [CrossRef]

8. Ozarowski, M.; Kujawski, R.; Mikołajczak, P.Ł.; Wielgus, K.; Klejewski, A.; Wolski, H.; Seremak-Mrozikiewicz, A. In vitro and in vivo activities of flavonoids-Apigenin, baicalin, chrysin, scutellarin-In regulation of hypertension-A review for their possible effects in pregnancy-induced hypertension. Herba Pol. 2019, 65, 55-70. [CrossRef]

9. Zhang, Q.; Wang, J.; Zhang, H.L.; Zeng, T. Dihydromyricetin inhibits oxidative stress and apoptosis in oxygen and glucose deprivation/reoxygenation-induced HT22 cells by activating the Nrf2/HO-1 pathway. Mol. Med. Rep. 2021, 6, 397. [CrossRef]

10. Ashaari, Z.; Hadjzadeh, M.A.R.; Hassanzadeh, G.; Alizamir, T.; Yousefi, B.; Keshavarzi, Z.; Mokhtari, T. The Flavone Luteolin Improves Central Nervous System Disorders by Different Mechanisms: A Review. J. Mol. Neurosci. 2018, 65, 491-506. [CrossRef]

11. Gunache, R.O.; Apetrei, C. Estimation of Active Compounds Quantity from Pharmaceuticals Based on Ginkgo biloba. Chemosensors 2020, 4, 110. [CrossRef]

12. Menshchikova, E.B.; Zenkov, N.K.; Kandalintseva, N.V. Phenolic Antioxidants in Biology and Medicine; Lap Lambert: Saarbrücken, Germany, 2012; p. 324.

13. Gupta, A.; Birhman, K.; Raheja, I.; Kumar Sharma, S.; Kumar Kar, H. Quercetin: A wonder bioflvonoid with therapeutic potential in disease management. Asian Pac. J. Trop. Dis. 2016, 6, 248-252. [CrossRef]

14. Cho, S.Y.; Park, S.J.; Kwon, M.J.; Jeong, T.S.; Bok, S.H.; Choi, W.Y.; Jeong, W.-I.; Ryu, S.-Y.; Do, S.-H.; Lee, C.-S.; et al. Quercetin suppresses proinflammatory cytokines production through MAP kinases and NF-kappaB pathway in lipopolysaccharidestimulated macrophage. Mol. Cell Biochem. 2003, 243, 153-160. [CrossRef] [PubMed] 
15. Calamia, K.T. Current and future use of anti-TNF agents in the treatment of autoimmune, inflammatory disorders. Adv. Exp. Med. Biol. 2003, 528, 545-549.

16. Xu, J.; Wang, H.; Lu, X.; Ding, K.; Zhang, L.; He, J.; Wei, W.; Wu, Y. Posttraumatic administration of luteolin protects mice from traumatic brain injury: Implication of autophagy and inflammation. Brain Res. 2014, 1582, 237-246. [CrossRef]

17. Sawmiller, D.; Li, S.; Shahaduzzaman, M.; Smith, A.J.; Obregon, D.; Giunta, B.; Borlongan, C.V.; Sanberg, P.R.; Tan, J. Luteolin reduces Alzheimer's disease pathologies induced by traumatic brain injury. Int. J. Mol. Sci. 2014, 15, 895-904. [CrossRef]

18. Sun, C.C.; Su, H.; Zheng, G.D.; Wang, W.J.; Yuan, E.; Zhang, Q.F. Fabrication and characterization of dihydromyricetin encapsulated zein-caseinate nanoparticles and its bioavailability in rat. Food Chem. 2020, 330, 127245. [CrossRef]

19. Tong, H.; Zhang, X.; Tan, L.; Jin, R.; Huang, S.; Li, X. Multitarget and promising role of dihydromyricetin in the treatment of metabolic diseases. Eur. J. Pharmacol. 2020, 870, 172888. [CrossRef]

20. Zhou, X.; Wang, F.; Zhou, R.; Song, X.; Xie, M. Apigenin: A current review on its beneficial biological activities. J. Food Biochem. 2017, 41, e12376. [CrossRef]

21. Ali, F.; Rahul; Naz, F.; Jyoti, S.; Siddique, Y.H. Health functionality of apigenin: A review. Int. J. Food Prop. 2017, 20 , 1197-1238. [CrossRef]

22. Ahad, A.; Ganai, A.A.; Mujeeb, M.; Siddiqui, W.A. Chrysin, an anti-inflammatory molecule, abrogates renal dysfunction in type 2 diabetic rats. Toxicol. Appl. Pharmacol. 2014, 279, 1-7. [CrossRef] [PubMed]

23. Veerappan, R.; Malarvili, T. Chrysin pretreatment improves angiotensin system, cGMP concentration in L-NAME induced hypertensive rats. Indian J. Clin. Biochem. 2018, 34, 288-295. [CrossRef] [PubMed]

24. Sowndhararajan, K.; Deepa, P.; Kim, M.; Park, S.J.; Kim, S. Neuroprotective and cognitive enhancement potentials of baicalin: A review. Brain Sci. 2018, 8, 104. [CrossRef]

25. Liang, W.; Huang, X.; Chen, W. The effects of baicalin and baicalein on cerebral ischemia: A review. Aging Dis. 2017, 8, 850-867. [CrossRef] [PubMed]

26. Gholampour, F.; Mohammadi, Z.; Karimi, Z.; Owji, S.M. Protective effect of genistein in a rat model of ischemic acute kidney injury. Gene 2020, 753, 144789. [CrossRef]

27. Banerjee, S.; Li, Y.; Wang, Z.; Sarkar, F.H. Multi-targeted therapy of cancer by genistein. Cancer Lett. 2008, 269, 226-242. [CrossRef] [PubMed]

28. Xin, X.; Chen, C.; Hu, Y.Y.; Feng, Q. Protective effect of genistein on nonalcoholic fatty liver disease (NAFLD). Biomed. Pharmacother. 2019, 117, 109047. [CrossRef] [PubMed]

29. Diukendjieva, A.; Zaharieva, M.M.; Alov, P.; Tsakovska, I.; Pencheva, T.; Najdenski, H.; Kren, V.; Felici, C.; Bufalieri, F.; Di Marcotullio, L.; et al. Dual SMO/BRAF Inhibition by Flavonolignans from Silybum marianum. Antioxidants 2020, 9, 384. [CrossRef]

30. Delmas, D.; Xiao, J.B.; Vejux, A.; Aires, V. Silymarin and Cancer: A Dual Strategy in Both in Chemoprevention and Chemosensitivity. Molecules 2009, 25, 2009. [CrossRef]

31. Mastron, J.K.; Siveen, K.S.; Sethi, G.; Bishayee, A. Silymarin and hepatocellular carcinoma: A systematic, comprehensive, and critical review. Anticancer Drugs 2015, 26, 475-486. [CrossRef]

32. Kawaii, S.; Tomono, Y.; Katase, E.; Ogawa, K.; Yano, M. Effect of coumarins on HL-60 cell differentiation of coumarins on HL-60 cell differentiation. Anticancer Res. 2000, 20, 2505-2512. [PubMed]

33. Kato, A.; Kobayashi, K.; Narukawa, K.; Minoshima, Y.; Adachi, I.; Hirono, S.; Nash, R.J. 6,7-Dihydroxy-4-phenylcoumarin as inhibitor of aldose reductase 2. Bioorg. Med. Chem. Lett. 2010, 20, 5630-5633. [CrossRef] [PubMed]

34. Zhu, L.J.; Lu, L.L.; Zeng, S.; Luo, F.F.; Dai, P.M.; Wu, P.; Wang, Y.; Liu, L.; Hu, M.; Liu, Z.Q. UDP-Glucuronosyltransferases 1 A6 and 1A9 are the Major Isozymes Responsible for the 7-O-Glucuronidation of Esculetin and 4-Methylesculetin in Human Liver Microsomes. Drug Metab. Dispos. 2015, 43, 977-983. [CrossRef] [PubMed]

35. Hadjipavlou-Litina, D.J.; Litinas, K.E.; Kontogiorgis, C. The Anti-inflammatory Effect of Coumarin and its Derivatives. Antiinflamm. Antiallergy Agents Med. Chem. 2007, 6, 293-306. [CrossRef]

36. Menshchikova, E.B.; Zenkov, N.K.; Lankin, V.Z.; Bondar, I.A.; Trufakin, V.A. Oxidative Stress: Pathologic States and Diseases; Sibirskoe Univ. Izd.: Novosibirsk, Russia, 2008; p. 534.

37. Menschikova, E.B.; Zenkov, N.K.; Lankin, V.Z.; Bondar, I.A.; Trufakin, V.A. Oxidative stress: Pathological Conditions and Diseases; ARTA: Novosibirsk, Russia, 2008; p. 435.

38. Galaris, D.; Barbouti, A.; Korantzopoulos, P. Oxidative Stress in Hepatic Ischemia-Reperfusion Injury: The Role of Antioxidants and Iron Chelating Compounds. Curr. Pharm. Des. 2006, 12, 2875-2890. [CrossRef]

39. Apak, R.; Capanoglu, E.; Shahidi, F. Measurement of Antioxidant Activity E Capacity: Recent Trends and Applications; Wiley-Blackwell: Hoboken, NJ, USA, 2018; p. 337.

40. Apak, R.; Özyürek, M.; Güçlü, K.; Çapanoğlu, E. Antioxidant Activity/Capacity Measurement. 1. Classification, Physicochemical Principles, Mechanisms, and Electron Transfer (ET)-Based Assays. J. Agric. Food Chem. 2016, 64, 997-1027. [CrossRef]

41. Apak, R.; Özyürek, M.; Güçlü, K.; Çapanoğlu, E. Antioxidant Activity/Capacity Measurement. 2. Hydrogen Atom Transfer (HAT)-Based, Mixed-Mode (Electron Transfer (ET)/HAT), and Lipid Peroxidation Assays. J. Agric. Food Chem. 2016, 64, 1028-1045. [CrossRef]

42. Perron, N.R.; Brumaghim, J.L. A Review of the Antioxidant Mechanisms of Polyphenol Compounds Related to Iron Binding. Cell Biochem. Biophys. 2009, 53, 75-100. [CrossRef] 
43. Huang, D.; Huang, D.; Ou, B.; Prior, R.L. The Chemistry behind Antioxidant Capacity Assays. J. Agric. Food Chem. 2005, 53, 1841-1856. [CrossRef]

44. Ivanova, A.V.; Gerasimova, E.L.; Brainina, K.Z. Potentiometric Study of Antioxidant Activity: Development and Prospects. Crit. Rev. Anal. Chem. 2015, 45, 311-322. [CrossRef]

45. Ivanova, A.; Gerasimova, E.; Gazizullina, E.; Popova, K.G.; Matern, A.I. Study of the antioxidant activity and total polyphenol concentration of medicinal plants. J. Anal. Chem. 2017, 72, 415. [CrossRef]

46. Ivanova, A.; Gerasimova, E.; Gazizullina, E.; Borisova, M.; Drokin, R.; Gorbunov, E.; Ulomskiy, E.; Rusinov, V. The antioxidant screening of potential materials for drugs based on 6-nitro-1,2,4-triazoloazines containing natural polyphenol fragments. Anal. Bioanal. Chem. 2020. [CrossRef] [PubMed]

47. Ivanova, A.V.; Gerasimova, E.L.; Gazizullina, E.R. New antiradical capacity assay with the use potentiometric method. Anal. Chim. Acta 2019, 1046, 69-76. [CrossRef] [PubMed]

48. Brainina, K.Z.; Ivanova, A.V.; Sharafutdinova, E.N.; Lozovskaya, E.L.; Shkarina, E.I. Potentiometry as a method of antioxidant activity investigation. Talanta 2007, 71, 13. [CrossRef] [PubMed]

49. Apak, R.; Gorinstein, S.; Böhm, V.; Schaich, K.M.; Özyürek, M.; Güçlü, K. Methods of measurement and evaluation of natural antioxidant capacity/activity (IUPAC Technical Report). Pure Appl. Chem. 2013, 85, 957-998. [CrossRef]

50. Spiegel, M.; Andruniów, T.; Sroka, Z. Flavones' and Flavonols' Antiradical Structure-Activity Relationship-A Quantum Chemical Study. Antioxidants 2020, 9, 461. [CrossRef] [PubMed]

51. Liu, L.; Ma, Z.; Zhu, X.; Zeng, R.; Tie, S.; Nan, J. Electrochemical behavior and simultaneous determination of catechol, resorcinol, and hydroquinone using thermally reduced carbonnano-fragment modified glassy carbon electrode. Anal. Methods 2016, 8, 605. [CrossRef]

52. Peng, J.; Gao, Z.N. Influence of micelles on the electrochemical behaviors of catechol and hydroquinone and their simultaneous determination. Anal. Bioanal. Chem. 2006, 384, 1525. [CrossRef] [PubMed]

53. Zhang, D.; Chu, L.; Liu, Y.X.; Wang, A.L.; Ji, B.P.; Wu, W.; Zhou, F.; Wei, Y.; Cheng, Q.; Cai, S.B.; et al. Analysis of the Antioxidant Capacities of Flavonoids under Different Spectrophotometric Assays Using Cyclic Voltammetry and Density Functional Theory. J. Agric. Food Chem. 2011, 59, 10277-10285. [CrossRef]

54. Amic, D.; Davidovic-Amic, D.; Beslo, D.; Rastija, V.; Lucic, B.; Trinajstic, N. SAR and QSAR of the antioxidant activity of flavonoids. Curr. Med. Chem. 2007, 14, 827.

55. Arteaga, J.F.; Ruiz-Montoya, M.; Palma, A.; Alonso-Garrido, G.; Pintado, S.; Rodríguez-Mellado, J.M. Comparison of the Simple Cyclic Voltammetry (CV) and DPPH Assays for the Determination of Antioxidant Capacity of Active Principles. Molecules 2012, 5, 5126-5138. [CrossRef] [PubMed]

56. Zhang, Q.; Türke, A.; Kilmartin, P. Electrochemistry of White Wine Polyphenols Using PEDOT Modified Electrodes. Beverages 2017, 3, 28. [CrossRef]

57. Tarantul, V.Z. Explanatory Dictionary of Molecular and Cellular Biotechnology; Russian Academy of Sciences: Moscow, Russia, 2015; p. 984.

58. Cao, S.J.; Lv, Z.Q.; Guo, S.; Jiang, G.P.; Liu, H.L. An update-Prolonging the action of protein and peptide drugs. J. Drug Deliv. Sci. Technol. 2021, 61, 102124. [CrossRef]

59. Jungbluth, G.; Ruhling, I.; Ternes, W. Oxidation of flavonols with $\mathrm{Cu}(\mathrm{II})$, Fe(II) and Fe(III) in aqueous media. J. Chem. Soc. Perkin Trans. 2 2000, 9, 1946-1952. [CrossRef]

60. Tang, Z.M.; Zhao, P.R.; Wang, H.; Liu, Y.Y.; Bu, W.B. Biomedicine Meets Fenton Chemistry. Chem. Rev. 2021, 121, 1981. [CrossRef]

61. Hippeli, S.; Elstner, E.F. Transition metal ion-catalyzed oxygen activation during pathogenic processes. FEBS Lett. 1999, $443,1-7$. [CrossRef]

62. Ivanova, A.; Gerasimova, E.; Gazizullina, E. Study of Antioxidant Properties of Agents from the Perspective of Their Action Mechanisms. Molecules 2020, 25, 4251. [CrossRef]

63. Lurie, J. Handbook of Analytical Chemistry; Mir Publishers: Moscow, Russia, 1975; p. 654.

64. Rusina, I.F.; Karpukhin, O.N.; Kasaikina, O.T. Chemiluminescent methods for studying inhibited oxidation. Russ. J. Phys. Chem. 2013, 7, 463-477. [CrossRef]

65. Mellado-Ortega, E.; Zabalgogeazcoa, I.; de Aldana, B.R.V.; Arellano, J.B. Solutions to decrease a systematic error related to AAPH addition in the fluorescence-based ORAC assay. Anal. Biochem. 2017, 519, 27-29. [CrossRef]

66. Lucarini, M.; Pedrielli, P.; Pedulli, G.F.; Valginigli, L.; Gigmes, D.; Tordo, P. Bond dissociation energies of the N-H bond and rate constants for the reaction with alkyl, alkoxyl, and peroxyl radicals of phenothiazines and related compounds. J. Am. Chem. Soc. 1999, 121, 11546-11553. [CrossRef]

67. Ivanova, A.V.; Gerasimova, E.L.; Gazizullina, E.R. An integrated approach to the investigation of antioxidant properties by potentiometry. Anal. Chim. Acta 2020, 1111, 83. [CrossRef] [PubMed] 